\author{
Bulat, A.F. ${ }^{1}$, Voloshyn, O.I. ${ }^{1}$, Potapchuk, I.Yu. ${ }^{1}$, Yemelianenko, V.I. ${ }^{1}$, \\ Zhovtonoha, M.M.' ${ }^{2}$, Zhevzhyk, O.V. ${ }^{2}$, and Manigandan, S. $^{3}$ \\ ${ }^{1}$ Institute of Geotechnical Mechanics named by N. Poljakov, the NAS of Ukraine, \\ 2a, Simferopolska St., Dnipro, 49005, Ukraine, \\ +380 56246 0151, +380 56246 2426, OIVoloshyn1951@nas.gov.ua \\ 2 Dnipropetrovsk National University of Railway Transport named after Academician V. Lazaryan, \\ 2, Lazaryan St., Dnipro, 49010, Ukraine, \\ +38056776 5947, +38056 247 1866, zvzk@ukr.net \\ ${ }^{3}$ Sathyabama Institute of Science and Technology, \\ Jeppiaar Nagar, Rajiv Gandhi Road, Chennai, 600 119, India, \\ 044-2450-3150, manisek87@gmail.com
}

\title{
MATHEMATICAL MODELING OF THE GAS DYNAMIC PARAMETERS OF IMPINGING HEAT-TRANSFER MEDIUM JET IN BOREHOLE THERMAL REAMING PROCESS
}

\footnotetext{
Introduction. As compared with other ways of thermal destruction of rocks, the rock destruction by low temperature plasma jet has advantage in terms of distribution of cracks in rock at a considerable depth, high heat transfer coefficient and high specific heat flux, simplified system of automation and remote control, and compactness of thermal tool.

Problem Statement. Thus, the possibilities of analytical determination of optimal parameters of thermal effect on rocks are limited by solution of thermoelasticity equations and contact problems of strength theory. Such formulation of the problem is unacceptable due to complication of taking into account substantial changes in the physical and thermos-physical rock properties while heating and applying mechanical load. Due to abovementioned facts it is obviously necessary to develop a mathematical model that enables to define basic gas dynamic jet parameters of heat-transfer medium in the process of borehole thermal reaming.

Purpose. The purpose of this research is to develop a mathematical model for calculating the gas dynamic characteristics (pressure, density, and velocity) of the heat-transfer medium while it is moving along the surface of the borehole in the thermal reaming process.

Materials and Methods. Mathematical modeling of the flow process for free and impact jets of heat-transfer medium using a $P C$.

Results. Experimental studies have confirmed adequacy of the developed mathematical model for calculation of gas dynamic characteristics (pressure, density, and velocity) of the heat-transfer while it is moving along the surface of the borehole in the process of its thermal reaming.

Conclusions. The obtained results can be used for modeling the gas dynamic characteristics in the case of applying a thermal tool with electric discharge in other technologies of heat treatment and destruction of materials.
}

Keywords: mathematical model, thermal reaming, borehole, and heat-transfer jet.

At the present time, the problems related to environment aspects of oil, gas, and geothermal well drilling in urban area are basic limitation for

(C) BULAT, A.F., VOLOSHYN, O.I., POTAPCHUK, I.Yu., YEMELIANENKO, V.I., ZHOVTONOHA, M.M., ZHEVZHYK, O.V., and MANIGANDAN, S., 2019 increasing the amount of such boreholes [1]. The use of plasma jet method enables to decrease rock hardness, which increases drilling velocity and reduces the costs.

A problem of mathematical modeling of the process of rock spallation reaming is urgent as 
well and it has been described in several publications [2-4].

In the modern mining, the thermal spallation reaming of rocks is used for quarrying, forming cavities and stimulating oil and gas production [5-7].

The latest domestic experimental and theoretical researches concerning the problems of destroying crystalline structures by plasma jets have been described in $[8,9]$.

The thermal reaming processes are used in other branches of engineering and industry.

In particular, developing mathematical models of thermal reaming and determining the service life of thermal barrier coatings used for manufacturing turbine blades, combustion chambers of turbo-engines, pipes of the boilers and other equipment are urgent tasks [10-13].

Theoretical and experimental research of rock thermal destruction by spallation is useful also for solving the problems in aerospace industry, particularly, for mathematical modeling of ablation processes during supersonic plasma jet interaction with the surface of solid bodies [14].

Among the known devices for thermal destruction of rocks the most advantageous are thermal tools with an arc electric discharge i.e. plasmatrons.

As compared with other ways of thermal destruction of rocks, the rock destruction by low temperature plasma jet has advantage in terms of distribution of cracks in rock at a considerable depth, high heat transfer coefficient and high specific heat flux, simplified system of automation and remote control, and compactness of thermal tool.

Mathematical description of analytical methods of thermal destruction and determination of optimal parameters of impact on rock have some specific features that must be taken into account for successful solution of the following problems of analytical thermal destruction theory:

+ determination of the temperature field induced by heat generator, i.e. plasmatron in the rock during its heating;
+ determination of the thermal stress field based on certain temperature field in the rock;

+ determination of the total field of thermal and mechanical stresses with the influence of the borehole taken into account;

+ determination of destruction surface and amount of destroyed rock as a result of thermal impact on it;

+ choice of optimal parameters of heat generator, heat exchange and operating conditions of thermal tool.

Thus, the possibilities of analytical determination of optimal parameters of thermal impact on rocks are limited by solution of thermoelasticity equations and contact problems of strength theory. Such a formulation of the problem is unacceptable due to complications related to consideration substantial changes in the physical and thermo-physical rock properties while heating and applying mechanical load.

Because of fundamental differences in the results of the known publications and the limitations of studied parameters of heat-transfer medium i.e. sonic or supersonic plasma jet that interacts with the borehole surface, it is obviously necessary to develop a mathematical model that enables to define basic gas dynamic jet parameters of heat-transfer medium in the process of borehole thermal reaming.

The following parameters are required as input data for the development of mathematical model for calculating gas dynamic properties of both free and semi-bounded gas jet:

+ the Mach number $M_{0}$ in the nozzle outlet, in the case of calculation of sonic and supersonic plasma jet flow (velocity of plasma jet outflow $u_{0}$ from nozzle);

+ diameter of nozzle outlet $d_{0}$;

+ distance from the plane of the nozzle outlet to the plane of the borehole $h$, where gas dynamic properties of the jet are calculated;

+ angle between the nozzle axis and the axis of the through duct $\varphi$.

The linear dimensions are expressed by diameters of the thermal tool nozzle outlet $d_{0}$ that is marked with a hyphen above characters. 
The parameters of heat-transfer medium at the nozzle outlet are as follows: static pressure $P_{s t}$, braking temperature $T_{0}{ }^{*}$, velocity of jet outflow from the nozzle $u_{0}$ and jet pressure ratio $n$ are determined based on the dependences [15]:

$$
P_{s t}=\frac{P_{n}}{\left(1+\frac{k-1}{2} \cdot M_{0}^{2}\right)^{\frac{k}{k-1}}},
$$

where $M_{0}$ is the Much number at the nozzle outlet; $P_{n}$ is heat-transfer medium pressure at the nozzle outlet; $k$ is ratio of specific heats of the heat transfer medium;

$$
n=\frac{P_{s t}}{P_{a t m}},
$$

where $P_{a t m}$ is atmospheric pressure.

The braking temperature of the heat-transfer medium at the nozzle outlet is determined from the ideal gas law, assuming the equality of braking temperature at any plane [15]:

$$
T_{0}^{*}=\frac{P_{n}}{\rho_{n} \cdot R} .
$$

where $\rho_{n}$ is heat-transfer medium density at the nozzle outlet; $R$ is the gas constant.

Velocity from the nozzle outflow is calculated by the following formula [15]:

$$
u_{0}=\sqrt{\frac{2 \cdot k}{k+1} \cdot R \cdot T_{0}^{*}} .
$$

The axial velocity distribution at the supersonic area of free jet flow is calculated [16] using the formula below:

$$
u_{a}=\frac{13 \cdot \sqrt{M_{e f}^{2}-1} \cdot\left(\frac{d_{e f}}{d_{0}}\right) \cdot u_{0}}{\bar{x}-\bar{S}},
$$

where $M_{e f}$ is the Mach number at the axis of jet in its "effective" plane; $d_{e f}$ is diameter of the jet "effective" plane; $\bar{x}$ is relative instantaneous coordinate along the axis of the cross duct; $\bar{S}$ is relative length of initial (gas dynamic) area of the jet.

The distribution of axial velocity at the subsonic area of free jet flow has been proposed by Mozhayeva [17]:

$$
u_{a}=\frac{8 \cdot u_{0}}{3.3+h}
$$

The Mach number at the axis of jet in its "effective" plane is calculated by the formula [16]:

$$
M_{e f}=\sqrt{\frac{F_{0}}{F_{e f}} \cdot\left(M_{0}^{2} \cdot n \cdot \cos ^{2} \alpha_{0}+\frac{n-1}{k}\right)},
$$

where $F_{0}$ is the area of nozzle outlet; $F_{e f}$ is the area of the jet "effective" plane; $\alpha_{0}$ is angle between the gas absolute velocity at the nozzle outlet and the axis of gas jet.

The diameter of jet "effective" plane has been expressed by Antsupov [18]:

$$
d_{e f}=d_{0} \cdot n^{0.6}
$$

Length of initial (gas dynamic) area of the jet is known from [19]:

$$
S=\left(4.2+1.1 \cdot M_{0}^{2}\right) \cdot d_{0} .
$$

Maximum pressure at the inner surface of the through duct [20] is:

$$
P_{\max \varphi}=\frac{\rho_{a t m} \cdot u_{a}^{2}}{2} \cdot \sin \varphi,
$$

where $\rho_{a t m}$ is heat-transfer medium density at the atmospheric pressure.

The critical point location (point of the maximum pressure at the inner surface of the cross duct) for $\bar{h}>6.2$ [21] is:

$$
{ }_{\Delta} \bar{x}=0.6 \cdot \bar{h}^{0.6} \cdot \cos \frac{3}{2} \cdot \varphi .
$$

Thus, distance along the inner surface of the through duct $\bar{x}$ starts from the critical point taking into account its displacement to the plane of the through duct along its lateral surface at a value $\Delta \bar{x}$.

In order to determine the type of semi-bounded jet flow along the inner surface of the through duct, it is necessary to calculate the length of the area of accelerating flow for $\bar{h}>6.2$ [17]:

$$
x_{*}=0.34 \cdot \bar{h}^{0.7} \cdot(1+0.25 \cdot \varphi) \cdot d_{0} .
$$

Maximum velocity at the outer boundary of the wall boundary layer is determined for $\bar{h}>6.2$ [21]:

$$
u_{*}=3.68 \cdot \bar{h}^{-0.84} \cdot u_{0} \cdot(1+\cos \varphi) .
$$




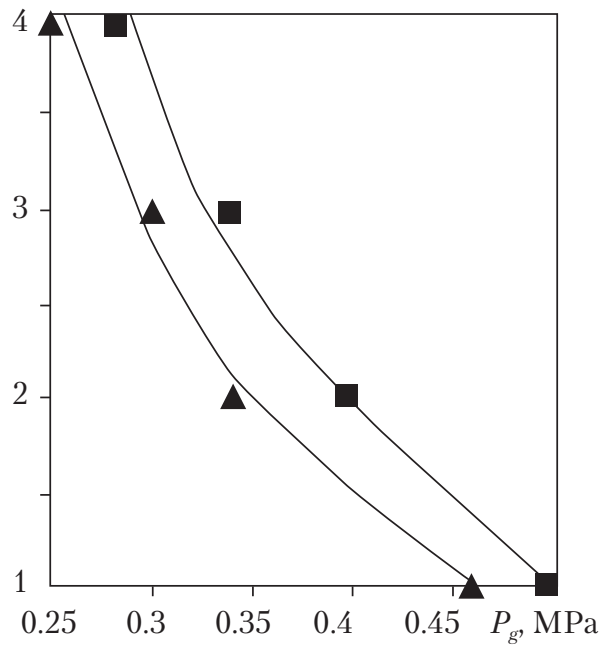

Verification of the mathematical model adequacy of the process of the heat transfer medium jet interaction with the lateral surface of the through ductthat imitated the surface of the borehole for conditions as follows: $P_{n}=1.1 \mathrm{MPa}, \bar{h}=12$, $\varphi=45^{\circ}$ (triangles depict experimental data, squares depict calculation results)

Velocity of the jet at the outer boundary of the wall boundary layer is determined by the following formulas:

for the area of accelerating flow [21]:

$$
u_{m}=\left[1.5 \cdot\left(\frac{x}{x_{*}}\right)-0.5 \cdot\left(\frac{x}{x_{*}}\right)^{3}\right] u_{*},
$$

where $x$ is spatial coordinate;

for the transient and the self-similar flow areas [21]:

$$
u_{m}=\left[1.8 \cdot(1+\cos \varphi) \cdot\left(\frac{d_{0}}{x}\right)^{0.5}\right] \cdot u_{*} .
$$

The boundary between the transient and the self-similar flow areas is determined by the expressions [21]:

for the branch with a higher gas flow rate:

$$
\bar{x}_{b n d}=\frac{3.24 \cdot(1+\cos \varphi)^{2}}{\left(\frac{u_{*}}{u_{0}}\right)^{2}} ;
$$

for the branch with a slower gas flow rate:

$$
\bar{x}_{b n d}=\frac{3.24 \cdot \sin ^{2} \varphi}{\left(\frac{u_{*}}{u_{0}}\right)^{2}} .
$$

Gauge static pressure along the lateral surface of the through duct has been determined by $\mathrm{Yu}$ dayev et al. [21]:

$$
P_{s t g}=\frac{\rho_{a t m} \cdot u_{a}^{2}}{2} \cdot \mathrm{e}^{-(c \cdot \bar{x})^{2}},
$$

where $c$ is coefficient.

The coefficient $c$ in equation (18) for $\bar{h}>6.2$ accordingly to [21] is equal to:

$$
c=5.04 \cdot \bar{h}^{-0.75} \text {. }
$$

Dynamic pressure of the heat-transfer medium along the lateral surface of the through duct is:

$$
P_{d y n}=\frac{\rho \cdot u_{m}^{2}}{2}
$$

where $\rho$ is instantaneous density of the heattransfer medium that is determined by static pressure of the heat-transfer medium.

Braking pressure of the heat-transfer medium along the lateral surface of the through duct is:

$$
P_{g}=P_{s t g}+P_{d y n} .
$$

The measured and the calculated values of gauge pressure of the heat-transfer medium on the lateral surface of the borehole depending on pressure of the heat-transfer medium at the nozzle outlet of thermal tool and on the distance from the plane of the nozzle outlet to the plane of the borehole is presented are compared in Fig. One can see that the results of experimental research have confirmed the adequacy of developed mathematical model.

The relative error of calculations of complete pressure of the heat-transfer medium on the lateral surface of the cross duct, i.e. on the rock surface does not exceed $22 \%$.

Mathematical modeling of gas dynamic properties of plasma jet interaction with the lateral surface of the borehole has been done.

The mathematical model that enables to calculate velocity of the heat-transfer medium along the lateral surface of the borehole as well as the distribution of density and pressure of the heattransfer medium on the lateral surface of the borehole has been proposed. 


\section{REFERENCES}

1. Bazargan, M., Gudmundsson, A., Meredith, P., Browning, J. \& Inskip, N. (2015, June). Wellbore instability during plasma torch drilling in geothermal reservoirs. $49^{\text {th }}$ US Rock Mechanics / Geomechanics Symposium, San Francisco.

2. Brkic, D., Kant, M., Meier, T., Schuler, M. \& von Rohr, R. (2015, April). Influence of Process Parameters on Thermal Rock Fracturing under Ambient Conditions. World Geothermal Congress, Melbourne.

3. Meier, T., May, D., von Rohr, P. (2016). Numerical investigation of thermal spallation drilling using an uncoupled quasi-static thermoelastic finite element formulation. Journal of Thermal Stresses, 39(9), 1138-1151.

4. Walsh, S., Lomov, I. (2013). Micromechanical modeling of thermal spallation in granitic rock. International Journal of Heat and Mass Transfer, 65, 366-373.

5. Potter, R., Potter, J., Wideman, T. (2010). Laboratory study and eld demonstration of hydrothermal spallation drilling. Geothermal Resources Council Transactions, 34, 249-252.

6. Stacey, R., Sanyal, S., Potter, J., Wideman, T. (2011). Effectiveness of selective borehole enlargement to improve flow performance of geothermal wells. Geothermal Resources Council Transactions, 35, 239-245.

7. Wideman, T., Sazdanoff, N., Unzelman-Langsdorf, J., Potter, J. (2011). Hydrothermal spallation for the treatment of hydrothermal and EGS wells: a cost-effective method for substantially increasing reservoir production and flow rates. Geothermal Resources Council Transactions, 35, 283-285.

8. Kleshchov, A. Y., Terentiev, O. M. (2014). Model eksperementalnykh doslidzhen ruinuvannia porody induktyvnoiu plazmoiu. Energetyka. Tekhnologiia, ekonomika, ekologiia, Spets. vyp., 51-54 [in Ukrainian].

9. Terentiev, O. M., Kleshchov, A. Y., Hontar, P. (2015). Planuvannia eksperymentu ruinuvannia krystalichnykh struktur potokamy induktyvnoi plazmy. Visnyk Ternopilskoho natsionalnoho tekhnichnoho universytetu, 1, 134-142 [in Ukrainian].

10. Wu, R., Osawa, M., Yokokawa, T., Kawagishi, G., Harada, H. (2010). Degradation mechanisms of an advanced jet engine service-retired TBC component. Journal of Solid Mechanics and Materials Engineering, 4(2), 119-130.

11. Renusch, D., Rudolphi, M., Schütze, M. (2010). Software tools for lifetime assessment of thermal barrier coatings. Part I - Thermal ageing failure and thermal fatigue failure. Journal of Solid Mechanics and Materials Engineering, 4(2), 143-154.

12. Yao, M., He, Y., Zhang, W., Gao, W. (2005). Oxidation resistance of boiler steels with $\mathrm{Al}_{2} \mathrm{O}_{3}-\mathrm{Y}_{2} \mathrm{O}_{3}$ nano- and micro-composite coatings produced by sol-gel process. Materials Transactions, 46(9), 2089-2092.

13. Bulat, A., Voloshyn, O., Zhevzhik, O. (2013). Plasma reactor for thermochemical preparation of coal-air mixture before its burning in the furnaces. Mining of Mineral Deposits, 39-44.

14. Kihara, H., Hatano, M., Nakiyama, N., Abe, K., Nishida, M. (2006). Preliminary studies of spallation particles ejected from an ablator. Transactions of the Japan Society for Aeronautical and Space Sciences, 49(164), 65-70.

15. Abramovich, G. N. (1991). Prikladnaya gazovaya dinamika. Moskva: Nauka.

16. Lukhtura, F. I. (1993). Odnomernaya teoriya sverkhzvukovykh neraschetnykh struy gaza. Izvestiya AN SSSR. Seriya Mekhanika zhidkosti i gaza, 1, 48-56 [in Russian].

17. Mozhayeva, Zh. P. (1978). Research of hydrodynamics and heat exchange at interaction of an axisymmetric turbulent jet with the barrier located under various corners to a stream. $\mathrm{PhD}$ (Tech.). Moscow [in Russian].

18. Antsupov, A. V. (1974). Issledovaniya parametrov neraschetnoy sverkhzvukovoy strui gaza. Zhurnal tekhnicheskoy fiziki, 44(2), 372-379 [in Russian].

19. Abramovich, G. N., Girshovich, T. A., Krasheninnikov, S. Yu. (1984). Teoriya turbulentnykh struy. Moskva: Mashinostroyeniye.

20. Savin, V. K., Mozhayeva, Zh. P., Aralov, A. D. (1975). Gidrodinamicheskiye issledovaniya pogranichnogo sloya pri struynom obtekanii plastiny. Izvestiya oysshykh uchebnykh zavedeniy. Seriya Mashinostroyeniye, 9, 76-80 [in Russian].

21. Yudayev, B. N., Mikhaylov, M. S., Savin, V. K. (1977). Teploobmen pri vzaimodeystvii struy s pregradami. Moskva: Mashinostroyeniye.

Received 10.08.18 


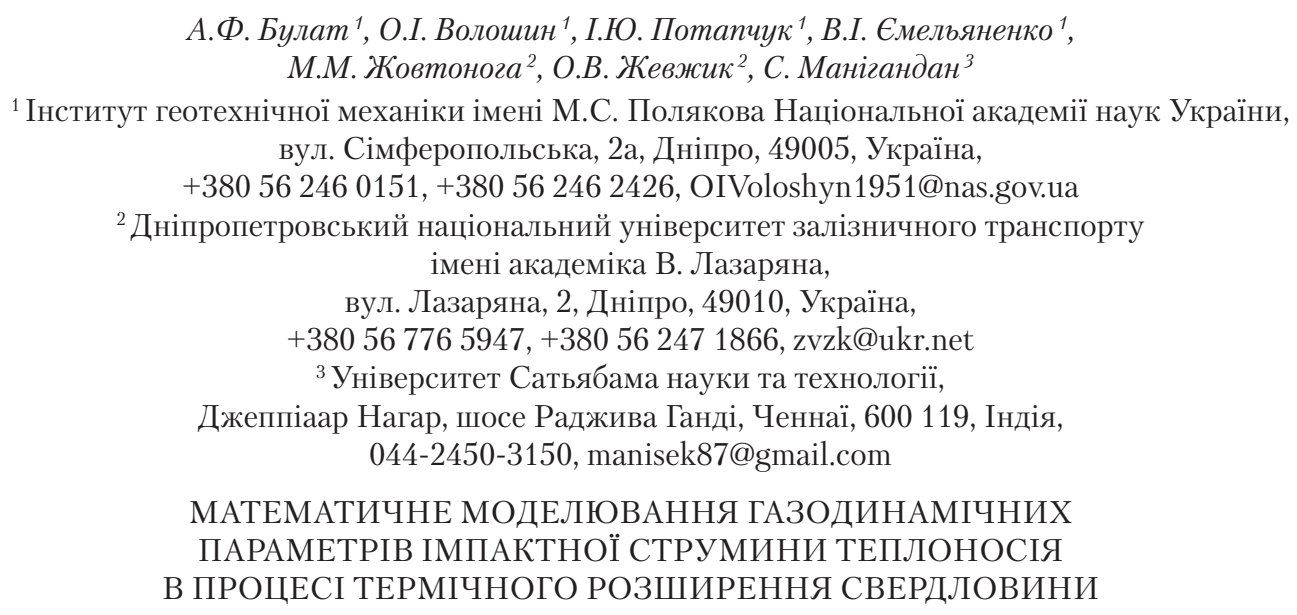

${ }^{3}$ Університет Сатьябама науки та технології,

Джеппіаар Нагар, шосе Раджива Ганді, Ченнаї, 600 119, Індія, 044-2450-3150, manisek87@gmail.com

\section{МАТЕМАТИЧНЕ МОДЕЛЮВАННЯ ГАЗОДИНАМІЧНИХ \\ ПАРАМЕТРІВ ІМПАКТНОЇ СТРУМИНИ ТЕПЛОНОСІЯ} В ПРОЦЕСІ ТЕРМІЧНОГО РОЗШИРЕННЯ СВЕРДЛОВИНИ

Вступ. Порівняно з іншими способами термічного руйнування гірських порід, руйнування породи за допомогою струмини низькотемпературної плазми відрізняється поширенням тріщин в породі на значну глибину, високими значеннями коефіцієнта тепловіддачі та питомого теплового потоку, спрощеною системою автоматизації та дистанційного управління, компактністю застосовуваного термоінструменту.

Проблематика. Можливості аналітичного визначення оптимальних параметрів термічного впливу на гірські породи обмежені розв’язанням рівнянь термопружності та контактних задач теорії міцності. Така постановка задачі $є$ неприйнятною через складність врахування суттевої зміни фізичних та теплофізичних властивостей гірських порід в процесі іх нагрівання та механічного навантаження. Зважаючи на це, очевидною є необхідність розробки математичної моделі, яка дозволяє визначити основні газодинамічні характеристики струмини теплоносія в процесі термічного розширення свердловини.

Мета. Розробка математичної моделі розрахунку газодинамічних характеристик (тиск, густина, швидкість руху) теплоносія при його русі вздовж поверхні свердловини в процесі її термічного розширення.

Матеріали й методи. Математичне моделювання процесу течії вільної та імпактної струмини теплоносія 3 використанням ПЕОМ.

Результати. Експериментальними дослідженнями підтверджено адекватність розробленої математичної моделі розрахунку газодинамічних характеристик (тиск, густина, швидкість руху) теплоносія при його русі вздовж поверхні свердловини в процесі їі термічного розширення.

Висновки. Отримані результати можуть бути використані для моделювання газодинамічних характеристик при застосуванні термоінструмента з дуговим електричним розрядом в інших технологіях термічної обробки та руйнування матеріалів.

Ключові слова: математична модель, термічне розширення, свердловина, струмина теплоносія. 


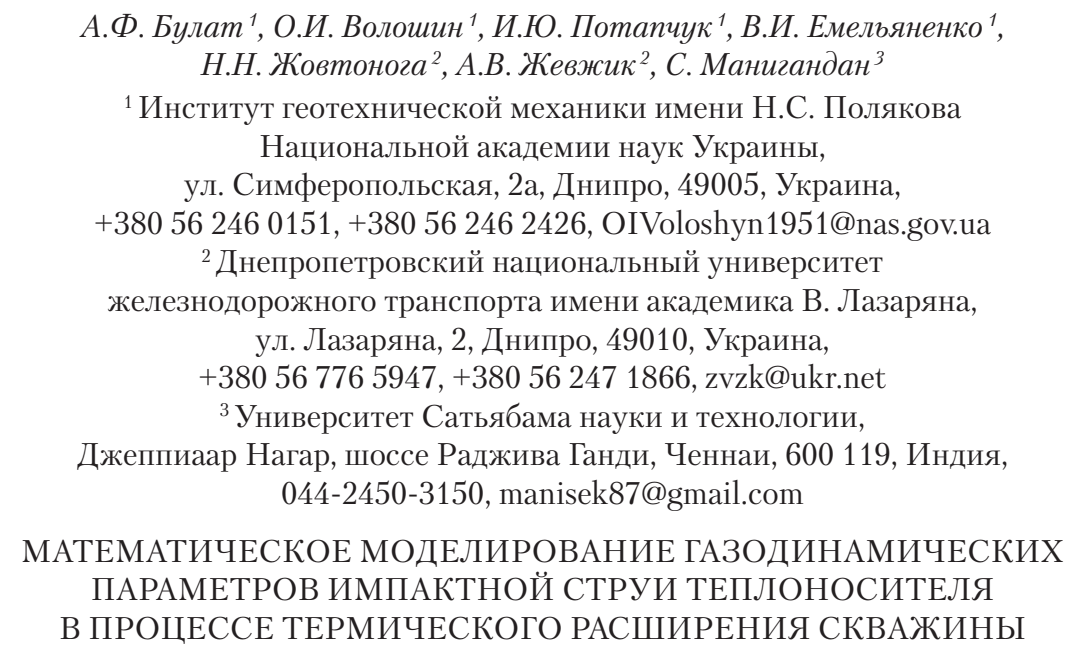

Введение. По сравнению с другими способами термического разрушения горных пород, разрушение породы с помощью струи низкотемпературной плазмы отличается распространением трещин в породе на значительную глубину, высокими значениями коэффициента теплоотдачи и удельного теплового потока, упрощенной системой автоматизации и дистанционного управления, компактностью термоинструмента.

Проблематика. Возможности аналитического определения оптимальных параметров термического влияния на горные породы ограничиваются решением уравнений термоупругости и контактных задач теории прочности. Такая постановка задачи является неприемлемой вследствие сложности учета существенного изменения физических и теплофизических свойств горных пород в процессе их нагревания и механического нагружения. В связи с этим очевидна необходимость разработки математической модели, которая позволяет определить основные газодинамические характеристики струи теплоносителя в процессе термического расширения скважины.

Цель. Разработка математической модели расчета газодинамических характеристик (давление, плотность, скорость движения) теплоносителя при его течении вдоль поверхности скважины в процессе ее термического расширения.

Материалы и методы. Математическое моделирование процесса течения свободной и импактной струи теплоносителя с использованием ПЭВМ.

Результаты. Экспериментальными исследованиями подтверждена адекватность разработанной математической модели расчета газодинамических характеристик (давление, плотность, скорость движения) теплоносителя при его движении вдоль поверхности скважины в процессе ее термического расширения.

Выводы. Полученные результаты могут быть использованы для моделирования газодинамических характеристик при применении термоинструмента с дуговым электрическим разрядом в других технологиях термической обработки и разрушения материалов.

Ключевые слова: математическая модель, термическое расширение, скважина, струя теплоносителя. 